\title{
Fresh banana pseudo-stems as a tropical lignocellulosic feedstock for methane production
}

\author{
Chao Li ${ }^{1,2^{*}}$ (D) Gangjin Liü ${ }^{2,3}$, Ivo A. Nges ${ }^{1}$, Liangwei Deng ${ }^{2}$, Mihaela Nistor ${ }^{3}$ and Jing Liu ${ }^{1,3}$
}

\begin{abstract}
Background: The banana pseudo-stem is a low-lignin-content lignocellulosic biomass that can be used for methane production. In recent years, anaerobic digestion (AD) of dried banana stems for methane production has attracted considerable attention. However, there is limited information regarding methane production from the fresh banana pseudo-stem. The direct usability of fresh banana stems as a resource for renewable energy production through AD is a called upon prerequisite for an improved waste management system culminating in a sustainable as well as socioeconomic development of local banana-producing communities.
\end{abstract}

Methods: In this study, three series of experiments were performed simultaneously to investigate the methane production from fresh banana pseudo-stems for the first time. The tests included size reduction, enzyme addition, and co-digestion of banana stems with cow manure.

Results: The achieved methane yields were 287,340 , to $347 \mathrm{~mL} \mathrm{~g}^{-1}$ volatile solids for the banana stem with particle sizes of 5, 10, and $20 \mathrm{~mm}$, respectively. The highest yield was obtained at the particle size of $20 \mathrm{~mm}$, showing a $21 \%$ increase compared to the particle size of $5 \mathrm{~mm}$. However, the particle size of $5 \mathrm{~mm}$ showed a high initial rate of hydrolysis evident by the highest hydrolysis rate constant of $0.152 \mathrm{~d}^{-1}$ as compared to $0.110 \mathrm{~d}^{-1}$ for the 20 -mm particle size. The addition of enzyme and co-digestion improved the rate of hydrolysis evident by a high rate constant as compared to the control though there was no improvement in the ultimate methane production.

Conclusions: This study demonstrates the usability of the fresh banana stem for efficient and high methane production after simply applying a minimal size reduction. The implementation of such a study will benefit society especially rural banana-producing areas both toward renewable energy generation and sustainable waste management. These could lead to job creation and an improved standard of living.

Keywords: Anaerobic digestion, Methane, Banana stems, Co-digestion, Enzymes, Biodegradability

\section{Background}

Bananas are widely consumed fruits with over 140 metric tons produced annually. India and China are leading banana producers owning about half of the total production [1]. Hainan is the largest tropical island in China, which had a population of $9,108,000$ people at the end of 2015 and harbors abundant biomass resources. In the agricultural sector, banana trees are widely planted and

\footnotetext{
*Correspondence: chao_h.li@biotek.lu.se

'Department of Biotechnology, Lund University, Naturvetarvägen 14, P.O. Box 124SE-221 00 Lund, Sweden

${ }^{2}$ Key Laboratory of Development and Application of Rural Renewable Energy, Ministry of Agriculture, Chengdu 610041, China

Full list of author information is available at the end of the article
}

the production has a primary economic importance. Annually, about 12.1 million tons of bananas are produced in China with 2.0 million tons coming from Hainan province. By using the residue/product ratio of 2.4 [2], 4.8 million tons of banana pseudo-stems, sheaths, central cylinders, and leaves is produced in Hainan province [3]. The stem which is the major component is often abandoned in the plantation or processed into low-grade animal feed by local farmers. However, these treatments may cause serious environmental and ecological problems such as eutrophication. On the other hand, the banana stem contains a large amount of biodegradable biomass 
that can be a potential resource. Therefore, it is imperative to find environmentally friendly methods for both pollutant control and efficient utilization of the waste biomass from the banana stem.

The anaerobic digestion (AD) process, where biogas can be generated and upgraded to bio-methane which can be a substitute for natural gas, is widely recognized as a promising technique for the treatment of various organic wastes $[4,5]$. However, low methane yield and poor substrate degradation rate are frequently reported when lignocellulosic biomasses are used as feedstock [6]. The recalcitrant structure of lignocellulosic wastes often requires suitable treatment to change its chemical and physical property in order to improve the biodegradability for enhanced methane production and substrate utilization [7]. In order to increase the rate of hydrolysis and optimize the biological conversion, physical, chemical, and biological pretreatments are often implemented, e.g., milling/grinding, acid or alkali treatment, and the addition of enzymes and microorganisms [6, 8-10]. Mechanical size reduction for banana stems could increase the rate of degradation and the methane yield by increasing the surface area of the substrates for an efficient enzymatic or microbial attack. Mild, environmentally friendly pretreatments using enzymes or cellulose-degrading microorganisms have provided another promising alternative for the enhancement of hydrolysis in the $\mathrm{AD}$ of lignocellulosic wastes $[8,9]$. Although the cost of enzymatic treatment is relatively high and enzyme activity can be lost to some extent, compared to pretreatments with microorganisms, enzymes can act in the presence of different toxic and recalcitrant feedstock with a low requirement to environmental conditions such as $\mathrm{pH}$, temperature, and salinity $[8,11]$. The above research activities provide some potential strategies to enhance the $\mathrm{AD}$ of lignocellulosic waste; however, to date, the pretreatment methods for improving methane production of tropical and subtropical lignocellulosic waste such as banana stems are still limited.

Considering the economic factors, some large fullscale biogas plants have already evaluated the feasibility of co-digesting manure with the banana stem in Hainan Island [12]. Banana stems and other tropical biomass can be used as supplementary substrates in the biogas plant for mitigating and optimizing both feedstock supply costs and environmental impact of livestock waste treatment. Moreover, the addition of suitable substrates can provide a better process stability by balancing the macro- and micronutrients and by avoiding the accumulation toxic by-products [13, 14]. Meanwhile, a wide range of nutrients and balanced $\mathrm{C} / \mathrm{N}$ ratio among co-digestion might avoid ammonia through simple dilution.
Studies on the AD of banana waste most often reported the pre-dried banana stem used as a substrate for methane production $[6,15,16]$. Since the banana stem is bulky in nature, the main constraint in the value chain will be drying to reduce bulkiness and ease of transport. However, dry substrates are prone to floatation in an anaerobic digester [14] and hence poor contact with the microbial consortium. Also, studies on methane production from wet or fresh banana stem are scarcely reported in scientific literature. It is, therefore, worth investigating the production of methane from wet or fresh banana stems.

The current study aimed primarily at evaluating the feasibility of using the fresh banana stem as feedstock for methane production and to concomitantly investigate the effects of physical (size reduction ranging from 5 to $20 \mathrm{~mm}$ ) and enzymatic treatment (Celluclast and MethaPlus) on the methane potential, biodegradability, and methane production rate. Co-digestion of the fresh banana stem with cow manure was also investigated to test the applicability of banana stem as a lignocellulosic co-substrate in methane production from animal manure. Such a study will therefore entail the transformation of waste into value-added products, thus addressing both the environmental pollution and inefficient utilization of resources. Generation of renewable energy from fresh banana stems could benefit rural communities which are often deprived of electrical energy. This may also reduce the dependence on firewood or charcoal which are known to provide for domestic energy requirements. Such a development could help save trees, lower emissions that cause climate change, and reduce the fumes from millions of tons of firewood that threaten the health of the improvised local communities.

\section{Methods}

\section{Substrates and inoculum}

The banana stem used in this study was collected from a banana farm in Yongzhuang village of Haikou city,

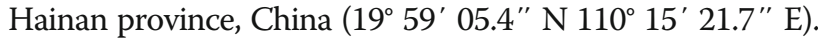
The tough outer waxy layers and inflorescence centers were handily separated, thereby keeping only the tender intermediary succulent section. The samples were well packed in gas-tight containers and transported to the Department of Biotechnology at the University of Lund, Sweden, within $24 \mathrm{~h}$. The substrate was stored in a refrigerator at $4{ }^{\circ} \mathrm{C}$ prior to use. The cow manure (CM) used as a co-substrate was obtained from an animal farm in Plönninge (Skåne, Sweden).

The inoculum used in the study was collected from a mesophilic biogas plant (Ellinge, Eslöv, Sweden) treating potato waste and sewage sludge. The particulate matter $(>1 \mathrm{~mm}$ ) was removed from the inoculum by passing through a 1-mm pore size sieve. The inoculum was 
stored at room temperature for 7 days under anaerobic conditions to decrease the endogenous methane production. The $\mathrm{pH}$ of the inoculum was 7.3, and the partial alkalinity was $3600 \mathrm{mg} \mathrm{L}^{-1}$. Other characteristics of the substrates and inoculum are presented in Table 1.

\section{Substrate pretreatments and co-digestion}

Three parallel batch $\mathrm{AD}$ tests were performed in the present study to investigate the effect of size reduction, enzyme addition, and co-digestion of the banana stem with $\mathrm{CM}$.

\section{Size reduction}

In order to study the effect of particle size on the AD process, the banana stems were manually peeled then sheared into small pieces with the aid of a scissor into three different particle sizes comprising 5, 10, and $20 \mathrm{~mm}$ thereof denoted as $\mathrm{B}_{5}, \mathrm{~B}_{10}$, and $\mathrm{B}_{20}$, respectively (Fig. 1). When cutting the banana stem, the juice from the banana stem was collected. However, liquid loss during the cutting procedure could not be totally avoided, a condition that led to the slight difference in the total solid (TS) and volatile solid (VS) values (Table 1).

\section{Enzymatic treatment}

Only the $B_{20}$ banana stem sample was investigated as per enzymatic treatment. The enzyme used in this study was a pure enzyme or mix enzyme. The first was a pure Celluclast (cellulase) $1.5 \mathrm{~L}$, obtained from Novozyme Inc. (Denmark) which was derived from Trichoderma reesei. The optimum activity was 700 endoglucanase (EGU) $\mathrm{g}^{-1}$ or 70 filter paper units (FPU) $\mathrm{g}^{-1}$ at $\mathrm{pH} 4.5-$ 6.0 and $50-60{ }^{\circ} \mathrm{C}$. The second was MethaPlus ${ }^{\circ}$ L100 obtained from DSM Biogas (Delft, Netherlands). MethaPlus $^{\oplus}$ L100 is a complex enzyme mixture which is active in a $\mathrm{pH}$ range of 4.5 to 8.0. Under typical methane fermentation conditions, MethaPlus ${ }^{\circ}$ L100 is active in a temperature range of $35-50{ }^{\circ} \mathrm{C}$. The enzymes (Celluclast $1.5 \mathrm{~L}$ and MethaPlus ${ }^{\circ} \mathrm{L} 100$ ) were added into the reactors prior to the $\mathrm{AD}$ assay of $\mathrm{B}_{20}$ wherein 0.19 and $1.14 \mathrm{~mL}$ of Celluclast was added corresponding to an enzyme load of 10 and $60 \mathrm{FPU} \mathrm{g}^{-1}$ VS. For MethaPlus ${ }^{\bullet}$ L100, $2.2 \mathrm{~mL}$ was added which corresponded to an enzyme loading $10 \mathrm{FPU} \mathrm{g}^{-1}$ VS (Fig. 1).

Table 1 Characteristics of substrates and inoculum

\begin{tabular}{lll}
\hline Substrates & TS (\%) & VS (\%) \\
\hline$B_{5}$ & $5.53 \pm 0.11$ & $4.47 \pm 0.05$ \\
$B_{10}$ & $5.00 \pm 0.34$ & $3.99 \pm 0.34$ \\
$B_{20}$ & $4.82 \pm 0.16$ & $3.78 \pm 0.23$ \\
$C M$ & $6.86 \pm 0.20$ & $5.81 \pm 0.21$ \\
Inoculum & $1.98 \pm 0.02$ & $1.15 \pm 0.02$ \\
\hline
\end{tabular}

$B_{5}$ banana particle size of $5 \mathrm{~mm}, B_{10}$ banana particle size of $10 \mathrm{~mm}, B_{20}$ banana particle size of $20 \mathrm{~mm}, C M$ cow manure, TS total solid (based on wet weight), VS volatile solid (based on wet weight)

\section{Co-digestion with cow manure}

The co-digestion test was performed with all three banana stem particle sizes $\left(B_{5}, B_{10}\right.$, and $\left.B_{20}\right)$. In order to investigate the performance of co-digestion by adding a small part of CM, two VS-based regimes were designed and tested, i.e., $15 \% \mathrm{CM}$ plus $85 \%$ banana stems and the second contained a higher amount of CM, i.e., $35 \%$ and a less fraction of the banana stem (65\%) (see Fig. 1).

\section{Biochemical methane potential tests}

Three series of biochemical methane potential (BMP) assays (Fig. 1), namely BMP of mechanical-pretreated samples (size reduction), BMP of enzyme-treated samples, and BMP of co-digested banana stem and CM, were performed in parallel with the aid of an automatic methane potential test system (AMPTS II) (Bioprocess Control AB, Sweden) under mesophilic conditions (37 \pm $0.5{ }^{\circ} \mathrm{C}$ ). The batch digestion trials were conducted in 15 reactors of $500 \mathrm{~mL}$ each. The substrates and inoculum were mixed at the ratio of 1:2 in terms of gram VS [17] to avoid potential substrate inhibition and low microbial density. All the reactors were sealed with rubber stoppers and connected to a mechanical agitator to provide complete mixing. During the test, only methane was measured as carbon dioxide was scrubbed off from the produced gas with the aid of concentrated $\mathrm{NaOH}$. A detailed description of the AMPTS is found in and the experimental protocol was performed according to previous studies by Badshah et al. [18].

One blank and two sets of controls were included in the test. In the blank experiment, only the inoculum was used to measure the indigenous methane production from the inoculum, which was subtracted from the total methane produced from all test samples. The positive control with cellulose (Avicel PH-101, Sigma-Aldrich, St. Louis, MO, USA) was used to give an idea of the inoculum response toward "standard" substrates. The BMP of Celluclast/MethaPlus was also evaluated (third control) and subtracted from the enzymetreated test samples. All tests were performed in triplicates and terminated after 34 days of incubation when the daily methane production was less than $1 \%$ of the total methane production. The methane produced was automatically normalized to standard conditions, i.e., $0{ }^{\circ} \mathrm{C}$ and $1013 \mathrm{hPa}$ by AMPTS software.

\section{Analytical methods}

The content of TS and VS of all the samples including those of the different particle sizes and $\mathrm{CM}$ was determined in triplicates according to standard methods [19]. The $\mathrm{pH}$ was measured by the automatic titrator TitroLine Easy (Schott Instrument, Germany). The content of hemicellulose, cellulose, and lignin were determined by analysis of neutral detergent fiber (NDF), 


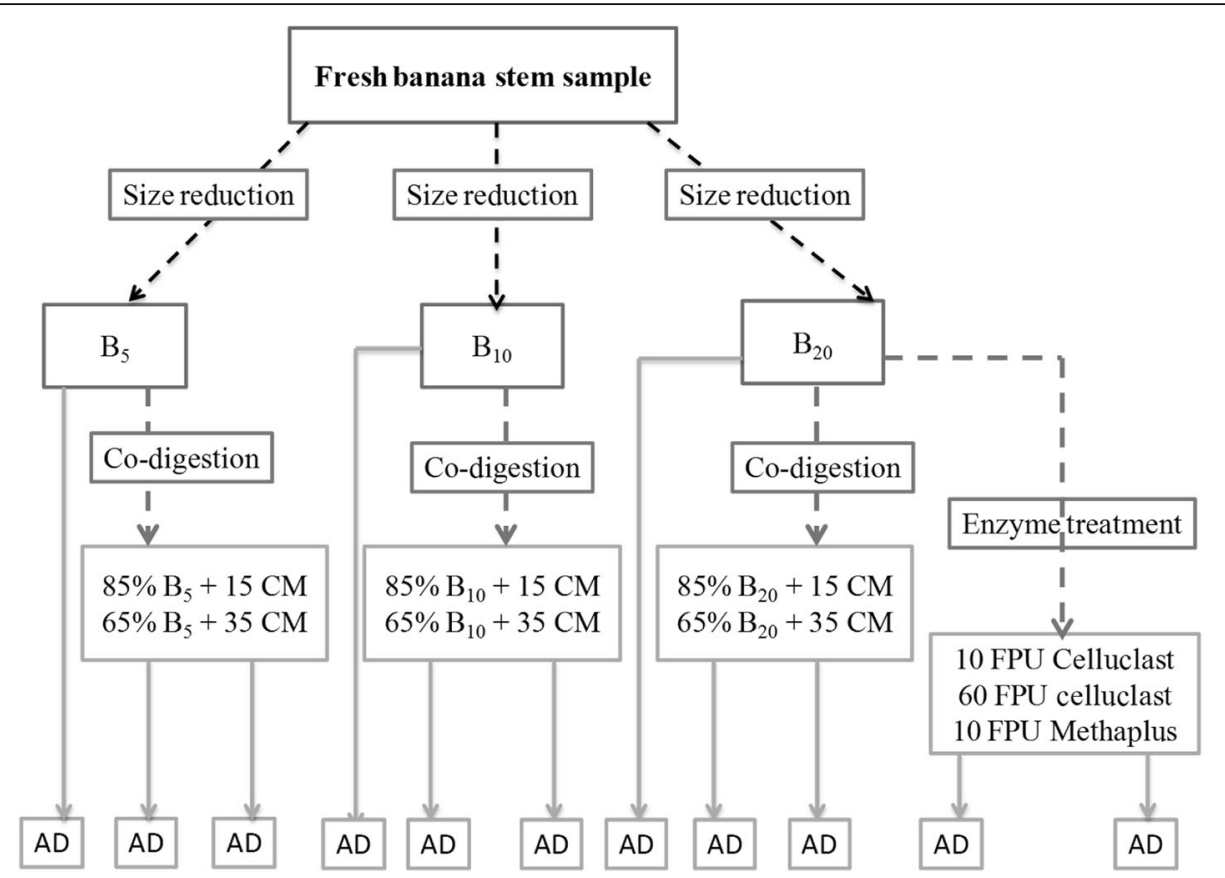

Fig. 1 Sketch of the experimental design and protocol where $B_{5}$ stands for the 5-mm samples, $B_{10}$ for the 10-mm samples, $B_{20}$ for the 20-mm samples, and $\mathrm{CM}$ for cow manure

acid detergent fiber (ADF), and acid detergent lignin (ADL) in ground samples as described in a previous study [20]. The elements of $\mathrm{C}, \mathrm{H}$, and $\mathrm{N}$ of the banana stems were determined using a CE-440 elemental analyzer (EAI Co., USA), while $\mathrm{S}$ and $\mathrm{O}$ were determined by a $5 \mathrm{E}-8 \mathrm{~S}$ II sulfur analyzer (Kaiyuan Co., China) and a PE 2400 II elemental analyzer (Perkin Elmer, USA), respectively. Chemical oxygen demand (COD) was determined with the aid of the Dr. Lange test kit LCK 914 (HACH LANGE GmbH, Germany).

\section{Kinetics}

According to the accumulation methane production curve, the first-order kinetic equation [21] was used to estimate the BMP. The first-order kinetic equation is listed as follows:

$$
\operatorname{BMP}(t)=\mathrm{BMP}_{\infty} \cdot(1-\exp (-k \cdot(t-\theta)))
$$

where $\operatorname{BMP}(t)$ is the methane potential $\left(\mathrm{N} \mathrm{mL} \mathrm{g}^{-1} \mathrm{VS}\right)$ at time $t$ (days), $\mathrm{BMP}_{\infty}$ is the maximum or ultimate methane potential $\left(\mathrm{N} \mathrm{mL} \mathrm{g}^{-1} \mathrm{VS}\right)$ of the substrate, $k$ is the rate constant or hydrolysis rate constant $\left(\mathrm{d}^{-1}\right)$, and $\theta$ is the lag time constant (days).

\section{Statistical analysis}

Dixon's test $(P \leq 0.05)$ was used to check for outliers in the replicate-BMP tests. One-way analysis of variance (ANOVA) was performed with the Statistical Package for the Social Science (SPSS), version 16, to assess statistical differences in methane yield between the various sample sizes, enzymatic treatments, and co-digestion at a $95 \%$ confidence level to accept or reject the null hypothesis.

\section{Results and discussion}

\section{Inoculum activity and substrate characterization}

The inoculum showed a good methanogenic activity which was deduced from the positive control experiment using cellulose as the substrate. The BMP value of cellulose was $368 \mathrm{~mL} \mathrm{~g}^{-1}$ VS after 34 days of digestion, which represented $89 \%$ of the theoretical yield of $415 \mathrm{~mL} \mathrm{~g}^{-1}$ VS [22, 23].

The banana stem is a cylinder of packed overlapping leaf sheaths which are very succulent and fleshy [15]. Both substrates (banana stem and CM) showed very high moisture contents which were above $93 \% \mathrm{w} / \mathrm{w}$ (Table 1). The main components in the banana stem were cellulose (30.08\%), hemicelluloses (27.79\%), and poor lignin content (6.08\%) (Table 2), making banana stems an ideal candidate for methane generation because of its low lignin content. Similar values have been reported in other studies wherein banana residues were used as feedstock in AD [16]. The ash content of the banana stem is about $20 \%$ expressed on DM which is presented mainly by potassium, calcium, and silicium salts that are considerably high when compared with other agricultural straw [24]. The $\mathrm{C} / \mathrm{N}$ ratio of the 
Table 2 Compositional analysis of banana pseudo-stem

\begin{tabular}{lc}
\hline Components/elements & Contents (\% TS) \\
\hline Cellulose & $30.08 \pm 1.86$ \\
Hemicellulose & $27.79 \pm 0.88$ \\
Lignin & $6.08 \pm 0.05$ \\
C & $38.44 \pm 0.42$ \\
H & $5.03 \pm 0.05$ \\
O & $43.10 \pm 0.32$ \\
N & $1.24 \pm 0.07$ \\
S & $0.09 \pm 0.01$ \\
\hline
\end{tabular}

banana stem was 31 , which is about or slightly higher than the maximum value of 30 wherein it has been reported to be favorable for methane production [14]. Manure, on the other hand, is known to show a rather low $\mathrm{C} / \mathrm{N}$ [25], a reason why banana stem and manure could be co-substrates of choice in methane production.

\section{Effect of particle sizes on methane production rate and BMP of banana stems}

Figure 2 shows the 34-day methane production rate (right axis) and cumulative methane yield (left axis) for the different particle sizes of banana stems. The $B_{5}$ showed the highest methane production rate on day 1 (69.5 $\mathrm{mL} \mathrm{g}^{-1} \mathrm{VS} \mathrm{d}^{-1}$ ) while $\mathrm{B}_{20}$ showed the lowest $\left(48.0 \mathrm{~mL} \mathrm{~g}^{-1} \mathrm{VS} \mathrm{d}^{-1}\right)$. These corresponded to hydrolysis constants simulated by the first-order equation of $0.15,0.12$, and $0.11 \mathrm{~d}^{-1}$ for $\mathrm{B}_{5}, \mathrm{~B}_{10}$, and $\mathrm{B}_{20}$, respectively $(P<0.01)$ (Table 3). As compared to other lignocellulosic substrates wherein two peaks are often noted [26], only one peak was observed in the present study. It is plausible to state that easily degradable non-structural carbohydrates and hemicelluloses (water soluble carbohydrates or water extractives), which are of smaller molecular weight and amorphous together with structural carbohydrates in the banana stem, were easily hydrolyzed by enzymes in the reaction broth [26, 27]. In all the tests $\left(B_{5}, B_{10}\right.$, and $\left.B_{20}\right)$, $90 \%$ of the methane was produced within 2 weeks of incubation (Fig. 2). The methane production rate showed an increasing trend wherein $B_{5}>B_{10}>B_{20}$, showing that the smaller the particle size, the higher the methane production rate.

The 34-day methane yields ( $\mathrm{mL} \mathrm{g}^{-1} \mathrm{VS}$ ) were $289 \pm$ $1.81,340 \pm 18.18$, and $347 \pm 15.85$ for $B_{5}, B_{10}$, and $B_{20}$, respectively, wherein there was no significant difference $(P \leq 0.05)$ between $B_{10}$ and $B_{20}$. On the other hand, the $\mathrm{B}_{5}$ methane yield was significantly lower $(P \leq 0.05)$ than $B_{10}$ and $B_{20}$. The methane yields, therefore, showed a decreasing trend wherein $B_{5}<B_{10}<B_{20}$ (Fig. 1), indicating an increase in methane yield with increasing particle size. The $\mathrm{B}_{20}$ and $\mathrm{B}_{10}$ showed a 20 and $18 \%$ increase in methane yield, respectively, as compared to $B_{5}$ which was significantly different $(P \leq 0.05)$. The results of decreasing BMP with decreasing particle size are in stark contrast with other studies where decreasing particle size has been reported to garner an improvement in methane yields [7, 26]. The explanation has liaised to morphological structures of the banana stem. The dermal tissues in the banana stem consist of well-defined epidermis with radial oblong, wide cells with thick cuticles [28]. When the banana stem was reduced in size by cutting, the highly concentrated juice from the oblong cells could have been lost. That is, the smaller the particle size, the more organic juice was lost. In fact, the COD of the clear juice collected during chopping of

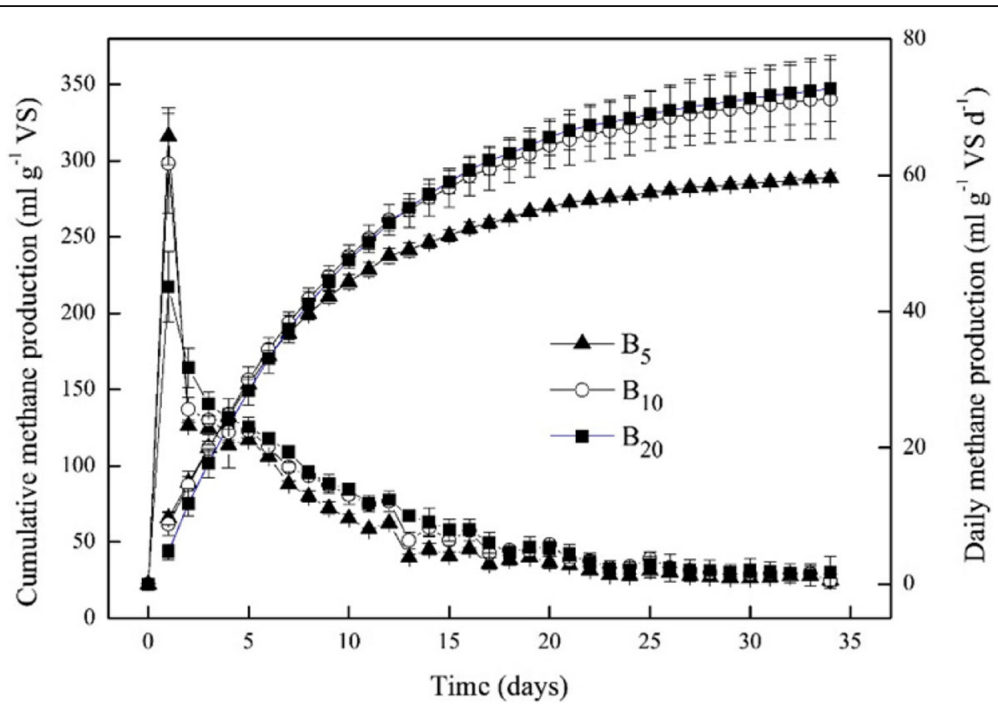

Fig. 2 Methane yields and methane production rates for the $5-\left(B_{5}\right), 10-\left(B_{10}\right)$, and 20-mm $\left(B_{20}\right)$ particle sizes of the banana stem 
Table 3 The simulation results of the anaerobic digestion process of banana stem with/without cow manure

\begin{tabular}{lcccl}
\hline Substrates & $\mathrm{BMP}\left(\mathrm{mL} \mathrm{g} \mathrm{g}^{-1} \mathrm{VS}\right)$ & $B_{\infty}$ & $k_{h}\left(\mathrm{~d}^{-1}\right)$ & $R^{2}$ \\
\hline $\mathrm{B}_{5}$ & $289 \pm 1.81$ & 285 & 0.153 & 0.999 \\
$\mathrm{~B}_{5}+15 \% \mathrm{CM}$ & $287 \pm 26.39$ & 281 & 0.145 & 0.983 \\
$\mathrm{~B}_{5}+35 \% \mathrm{CM}$ & $311 \pm 3.20$ & 304 & 0.152 & 0.984 \\
$\mathrm{~B}_{10}$ & $340 \pm 18.18$ & 343 & 0.120 & 0.995 \\
$\mathrm{~B}_{10}+15 \% \mathrm{CM}$ & $290 \pm 16.39$ & 289 & 0.136 & 0.997 \\
$\mathrm{~B}_{10}+35 \% \mathrm{CM}$ & $278 \pm 8.34$ & 277 & 0.148 & 0.997 \\
$\mathrm{~B}_{20}$ & $347 \pm 15.85$ & 354 & 0.110 & 0.999 \\
$\mathrm{~B}_{20}+15 \% \mathrm{CM}$ & $296 \pm 19.03$ & 296 & 0.112 & 0.998 \\
$\mathrm{~B}_{20}+35 \% \mathrm{CM}$ & $322 \pm 9.18$ & 328 & 0.116 & 0.998 \\
$\mathrm{~B}_{20}+10 \mathrm{FPU}(\mathrm{C} 15 \mathrm{~L})$ & $320 \pm 20.60$ & 337 & 0.101 & 0.996 \\
$\mathrm{~B}_{20}+60 \mathrm{FPU}(\mathrm{C} 15 \mathrm{~L})$ & $343 \pm 14.20$ & 343 & 0.136 & 0.983 \\
$\mathrm{~B}_{20}+10 \mathrm{FPU}(\mathrm{Met} 100)$ & $336 \pm 31.10$ & 345 & 0.114 & 0.996 \\
\hline
\end{tabular}

samples showed an organic content value (dissolved COD) of $4401 \mathrm{mg} \mathrm{L}^{-1}$. It is plausible, therefore, to state that banana juice contains soluble organic compounds, easily convertible to methane that could have been lost during extreme size reduction. This may also occur during drying prior to AD. This hypothesis may explain why the methane yields in the present study, using wet/ fresh banana stem, are significantly higher than those reported in studies wherein pre-dried samples are used. Another plausible explanation is the decrease in particle size increased the surface area of the banana stem that made it more accessible for the bacterial/enzymatic attack, thus leading to an accelerated hydrolysis evident by the increasing of the hydrolysis constant. It is probable that the accelerated hydrolysis may have led to the accumulation of volatile fatty acids which might have inhibited the biogas process and hence the poor BMP values $[29,30]$. Results also showed that the larger particle size $\left(\mathrm{B}_{20}\right)$ had the highest biodegradability.

\section{Effect of enzyme addition on the BMP of $B_{20}$ banana stem samples}

Only the larger particle size $\left(B_{20}\right)$ was used in the enzymatic treatment. The 34-day methane production rates (right axis) and cumulative methane yields (left axis) from the $B_{20}$ banana stem samples with and without enzyme addition are demonstrated in Fig. 3 . The test with an enzyme load of $60 \mathrm{FPU} \mathrm{g}^{-1} \mathrm{VS}$ showed the highest methane production rate of $67 \mathrm{~mL} \mathrm{~g}^{-1} \mathrm{VS} \mathrm{d}^{-1}$ on day 1 . This finding was correlated by the highest hydrolytic rate constant $\left(k_{h}\right)$ presented in Table 3 . As with the tests with the different particles sizes, $90 \%$ of the total methane was produced within 2 weeks of incubation and methane production showed a one-peak curvature. The entire enzyme-treated samples showed similar methane yields, which were $320 \pm 20.60,343 \pm$ 14.20, and $336 \pm 31.10 \mathrm{~mL} \mathrm{~g}^{-1} \mathrm{VS}$ for $10 \mathrm{FPU}$ Celluclast, 60 FPU Celluclast, and 10 FPU MethaPlus, respectively. Analysis of variance $(P \leq 0.05)$ showed that these methane yields did not differ significantly between them and the control (no enzyme addition). These findings are in line with other studies where insignificant changes in BMP were obtained when enzymes were added to lignocellulosic wastes [22, 31]. The BMP may not improve after enzyme addition in AD systems; nevertheless, a considerable improvement of the hydrolysis rate can be achieved [31]. In this study, a higher hydrolysis rate was obtained as compared to the control experiment

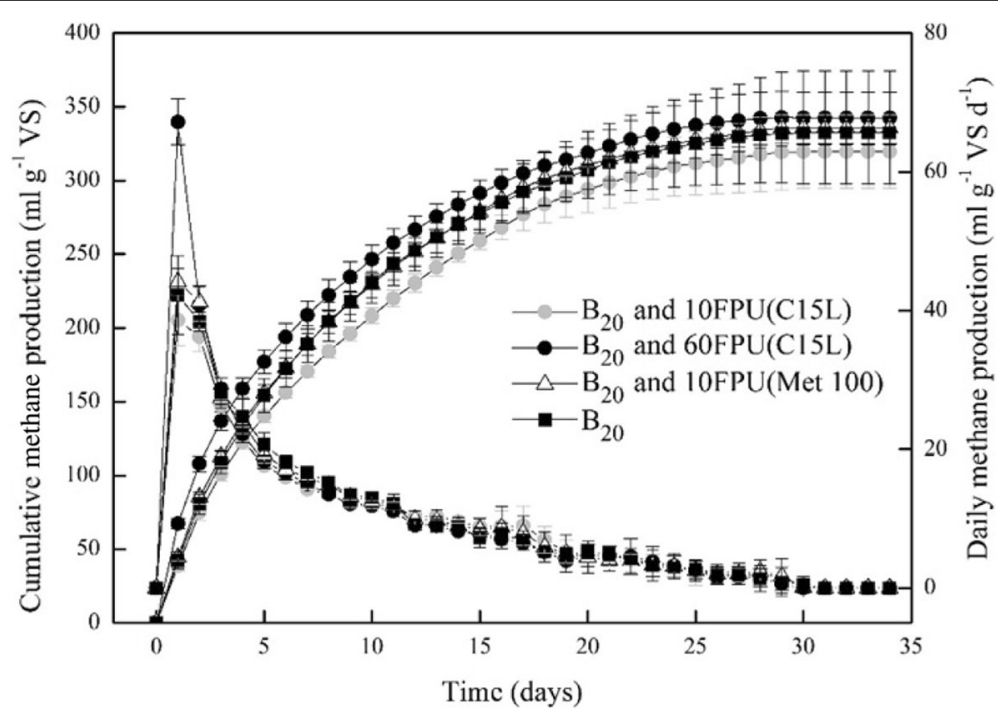

Fig. 3 Methane production rates of banana stems with and without enzyme addition. FPU stands for filter paper units, C15L stands for Celluclast, and Met stands for MethaPlus 
when a higher dose of Celluclast was added in the reactors. Both enzymes used in the present study were cellulolytic in nature, meaning that they can break down cellulose to easily convertible glucose molecules. However, cellulolytic microbes are known to evolve as individual degraders or as part of a "chain reaction" in microbial communities breaking down cellulose [32] in some environments such as AD processes [26].

\section{Effect of co-digestion with different fractions of manures on AD of banana stem samples}

The methane production rate (right axis) and cumulative methane yield (left axis) of the three different particle sizes of banana stem co-digested with 15 and $35 \%$ g VS of $\mathrm{CM}$ are displayed in Fig. 4. The co-digestion of $\mathrm{B}_{5}$ with $35 \% \mathrm{CM}$ showed the highest methane production rate peaking at $74 \mathrm{~mL} \mathrm{~g}^{-1} \mathrm{VS} \mathrm{d}^{-1}$ (Fig. 4b) while it was $66 \mathrm{~mL} \mathrm{~g}^{-1} \mathrm{VS} \mathrm{d}^{-1}$ (Fig. 4a) when a lower amount of CM
( $\mathrm{B}_{5}$ with $15 \% \mathrm{CM}$ ) was added. Meanwhile, the $k_{h}$ values were in the same range, i.e., 0.148 and $0.152 \mathrm{~d}^{-1}$, respectively. Both the results were not significant $(P>0.05)$.

The methane yields of $\mathrm{B}_{5}$ co-digested with 15 and $35 \%$ of $\mathrm{CM}$ were $287 \pm 26.39$ and $311 \pm 3.20 \mathrm{~mL} \mathrm{~g}^{-1} \mathrm{VS}$, respectively. The methane yields were $290 \pm 16.39$ and $278 \pm 8.34 \mathrm{~mL} \mathrm{~g}^{-1} \mathrm{VS}$ for $\mathrm{B}_{10}$ and $296 \pm 19.03$ and $322 \pm$ $9.18 \mathrm{~mL} \mathrm{~g} \mathrm{~g}^{-1}$ VS for $\mathrm{B}_{20}$, both co-digested with 15 and $35 \%$ of $\mathrm{CM}$ addition, respectively. The results show that co-digestion did not lead to a significant $(P \leq 0.05)$ improvement in methane yield. In fact, for $B_{10}$ and $B_{20}$, mono-digestion showed significantly higher methane yields $(P \leq 0.05)$. Co-digestion may lead to either synergy wherein higher yields are achieved through the provision of vital nutrients and buffering or antagonism where lower yields are obtained [14]. In the present study, it is probable that the inoculum was rich in buffering (partial alkalinity was $3600 \mathrm{mg} \mathrm{L}^{-1}$ ) and may have contained the
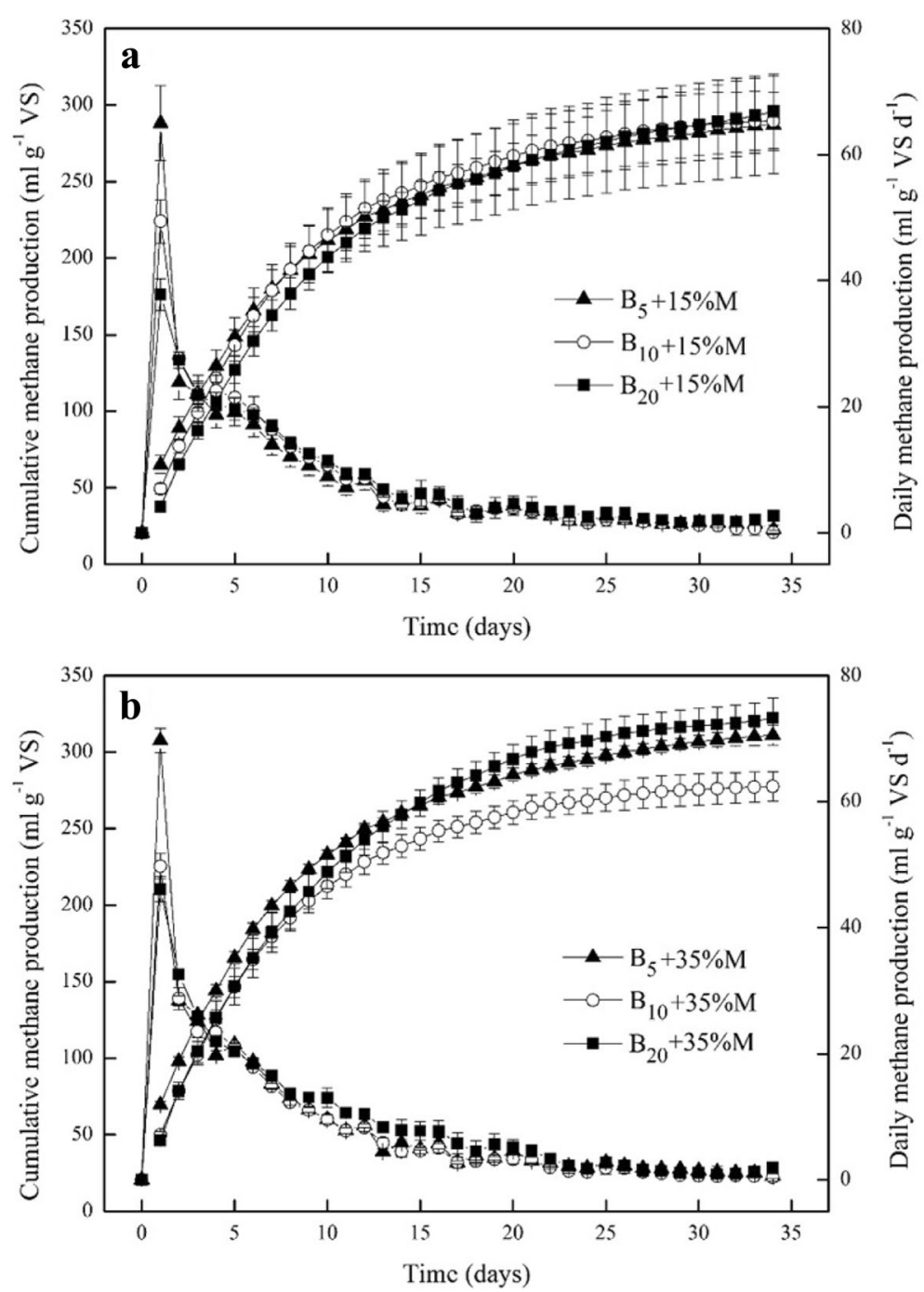

Fig. 4 Methane yields and methane production rates of $B_{5}, B_{10}$, and $B_{20}$ samples with $15 \%(\mathbf{a})$ and $35 \%$ (b) of cow manure 
necessary nutrients and cofactors needed for the biochemistry of methane production.

Though many studies have shown an improvement of anaerobic co-digestion compared to the mono-digestion $[33,34]$, this study showed that mono-digestion was a better option in terms of methane yields as compared to co-digestion. This might be because of the appropriate $\mathrm{C} / \mathrm{N}$ of the banana stem for $\mathrm{AD}$ and the fact that the inoculum used in the present study showed a rather high partial alkalinity. The above conditions should have provided a conducive environment for the mono- $\mathrm{AD}$ of the banana stem.

\section{The energy potential of fresh pseudo-banana stem}

Many studies have reported the BMP of dried banana stem to range from 195 to $256 \mathrm{~mL} \mathrm{~g}^{-1}$ VS [35-38]; these yields are much lower than the value obtained in this study. This disparity can be attributed to the fresh or wet nature of the banana stem used in the present study. It is probable that high moisture aided the biodegradability or putrescibility through providing an initial richer medium for enzymatic attack and hence methanogenesis [39]. Water is consumed during hydrolysis of macromolecules, and it has been reported that below a certain moisture content $(<25 \%)$, no biodegradation is known to take place [40]. Pommier et al. also reported a linear correlation between methane production and moisture content. On the other hand, drying may lead to the floatation of biomass and constriction, shrinkage, and loss of porosity in the cells making it inaccessible to enzymatic attack through decreased surface area to volume ratio. As mentioned earlier, the sap or liquid fraction of the banana stem may be rich in soluble, easily convertible organics to methane, which are otherwise lost during drying. Bound water (water contained in substrate or moisture) is therefore essential for an effective and efficient $\mathrm{AD}$ process. Increase moisture therefore favors bacterial/methanogen-waste colonization. Increased moisture containment also leads to an increase in water activity which has been reported to positively correlate with bacterial/archaea growth and hence methane production [41]. Water content may therefore positively impact methane production through increased microbial growth rate and bioavailability of solid banana waste [42]. It must be mentioned that the use of wet banana stem in lieu of dry sample may present some logistic and conservation problems. Nonetheless, the fresh banana stem can be preserved via ensiling or co-ensiling with other fractions of the banana plant waste such as leaves and peels.

A full-scale, continuous stirred tank biogas plant can therefore be operated with the pseudo-banana stem as the sole substrate or co-digested with manure. Considering the $4.8 \times 10^{6}$ tons of wet banana stem produced in
Hainan province and chopped to a particle size of $20 \mathrm{~mm}$ having a VS of $3.78 \% w / w$ and a BMP of $347 \mathrm{~m}^{3}$ ton $^{-1}$ VS, the yearly methane production could sum up to $6.29 \times 10^{7} \mathrm{~m}^{3} \mathrm{CH}_{4}$. This corresponds to a calorific or lower heating value of $2.26 \times 10^{11} \mathrm{~kJ} \mathrm{year}^{-1}$ $\left(1 \mathrm{~m}^{3}=35,900 \mathrm{~kJ}\right)$ or $0.63 \mathrm{GWh}$ year $^{-1}\left(1 \mathrm{~m}^{3}=9.97 \mathrm{kWh}\right)$ [16]. Paying cognizance of a conversion efficiency of $43 \%$, the yearly energy recovery from banana stem could amount to $0.27 \mathrm{GWh}_{\mathrm{year}}{ }^{-1}$. This can account for $1.46 \%$ of the yearly power consumption in Hainan province. Thus, it is plausible to state that the banana stem contains a huge amount of energy that can be harnessed through AD.

\section{Conclusions}

This present study demonstrated that wet banana stems can be used as substrates in both mono- and co-digestion processes with cow manure. The methane production of the fresh banana stem as a mono-substrate could reach $347 \mathrm{~mL} \mathrm{~g}^{-1} \mathrm{VS}$, which is higher than the reported values from other lignocellulosic biomasses and especially dried banana stems. Mechanical cutting to a desirable size was deemed the most economically viable option due to a possibly less energy requirement and high achievable methane yield. The results of enzyme addition and the co-digestion with cow manure showed a limited improvement of methane production for the banana stem, while the hydrolysis rates were improved. In addition, in all the tests, $90 \%$ of the total methane was produced within 2 weeks of incubation. Fresh banana stems can, therefore, become a cheap lignocellulosic substrate for methane production especially through co-ensiling with other morphological fractions for better storage or preservation.

\section{Acknowledgements}

The authors would like to thank the lab work support of Ms. Jinhua Chen. The authors wish to express their gratitude to the Agricultural Departments of the Hainan Provincial Government. The Open Fund of Key Laboratory of Development and Application of Rural Renewable Energy (2015014), Ministry of Agriculture in China, is gratefully acknowledged for the financial support.

\section{Authors' contributions \\ $\mathrm{CL}$ conceived the study, initiated the collaboration with the partner, and handled both the collection of the data and the drafting of the manuscript. IAN and MN participated in the design of the study and took the lead in the collection and analysis of the literature material and the REEP House data; GL led the drafting of the manuscript. LD and JL contributed to the development of the literature review and the drafting of the manuscript. All authors read and approved the final manuscript.}

\section{Competing interests}

The authors declare that they have no competing interests.

\section{Author details}

'Department of Biotechnology, Lund University, Naturvetarvägen 14, P.O. Box 124SE-221 00 Lund, Sweden. ${ }^{2}$ Key Laboratory of Development and Application of Rural Renewable Energy, Ministry of Agriculture, Chengdu 610041, China. ${ }^{3}$ Bioprocess Control, Scheelevägen 22, SE-223 63 Lund, Sweden. 
Received: 17 July 2016 Accepted: 12 September 2016 Published online: 03 October 2016

\section{References}

1. Padam BS, Tin HS, Chye FY, Abdullah MI (2014) Banana by-products: an under-utilized renewable food biomass with great potential. J Food Sci Technol 51(12):3527-3545

2. Yamaguchi J, Araki S (2004) Biomass production of banana plants in the indigenous farming system of the East African Highland: a case study on the Kamachumu Plateau in northwest Tanzania. Agric Ecosyst Environ 102(1):93-111

3. Mohapatra D, Mishra S, Sutar N (2010) Banana and its by-product utilization: an overview. J Sci Ind Res 69(5):323-329

4. Neves LC M d, Converti A, Vessoni Penna TC (2009) Biogas production: new trends for alternative energy sources in rural and urban zones. Chem Eng Technol 32(8):1147-1153

5. Scholz M, Alders M, Lohaus T, Wessling M (2015) Structural optimization of membrane-based biogas upgrading processes. J Membr Sci 474:1-10

6. Zhang C, Li J, Liu C, Liu X, Wang J, Li S, Fan G, Zhang L (2013) Alkaline pretreatment for enhancement of biogas production from banana stem and swine manure by anaerobic codigestion. Bioresour Technol 149:353-358

7. Taherzadeh MJ, Karimi K (2008) Pretreatment of lignocellulosic wastes to improve ethanol and biogas production: a review. Int J Mol Sci 9(9): $1621-1651$

8. Parawira W (2012) Enzyme research and applications in biotechnological intensification of biogas production. Crit Rev Biotechnol 32(2):172-186

9. Herbel Z, Rákhely G, Bagi Z, Ivanova G, Ács N, Kovács E, Kovács KL (2010) Exploitation of the extremely thermophilic Caldicellulosiruptor saccharolyticus in hydrogen and biogas production from biomasses. Environ Technol 31(8-9):1017-1024

10. Wang H, Tao Y, Temudo M, Schooneveld M, Bijl H, Ren N, Wolf M, Heine C, Foerster A, Pelenc V (2015) An integrated approach for efficient biomethane production from solid bio-wastes in a compact system. Biotechnol for biofuels 8(1):1

11. Gianfreda L, Rao MA (2004) Potential of extra cellular enzymes in remediation of polluted soils: a review. Enzym Microb Technol 35(4):339-354

12. Pei P, Zhang C, Li J, Chang S, Li S, Wang J, Zhao M, Li J, Yu M, Chen X (2014) Optimization of $\mathrm{NaOH}$ pretreatment for enhancement of biogas production of banana pseudo-stem fiber using response surface methodology. Bio Resources 9(3):5073-5087

13. Scano EA, Asquer C, Pistis A, Ortu L, Demontis V, Cocco D (2014) Biogas from anaerobic digestion of fruit and vegetable wastes: experimental results on pilot-scale and preliminary performance evaluation of a full-scale power plant. Energy Convers Manag 77:22-30

14. Nges IA, Escobar F, Fu X, Björnsson L (2012) Benefits of supplementing an industrial waste anaerobic digester with energy crops for increased biogas production. Waste Manage 32(1):53-59

15. Tock JY, Lai CL, Lee KT, Tan KT, Bhatia S (2010) Banana biomass as potential renewable energy resource: a Malaysian case study. Renew Sust Energ Rev 14(2):798-805

16. Kamdem I, Hiligsmann S, Vanderghem C, Bilik I, Paquot M, Thonart P (2013) Comparative biochemical analysis during the anaerobic digestion of lignocellulosic biomass from six morphological parts of Williams Cavendish banana (Triploid Musa AAA group) plants. World J Microbiol Biotechnol 29(12):2259-2270

17. Raposo F, De la Rubia M, Fernández-Cegrí V, Borja R (2012) Anaerobic digestion of solid organic substrates in batch mode: an overview relating to methane yields and experimental procedures. Renew Sust Energ Rev 16(1):861-877

18. Badshah M, Lam DM, Liu J, Mattiasson B (2012) Use of an automatic methane potential test system for evaluating the biomethane potential of sugarcane bagasse after different treatments. Bioresour Technol 114:262-269

19. APHA (2005) Total, fixed, and volatile solids in solid and semisolid samples In: Eaton AD, Clesceri LS, Rice EW, Greenberg AE, Franson MA (eds) Standard methods for the examination of water and wastewater, 21st edn. American Public Health Association/American Water Works Association/ Water Environment Federation, Baltimore
20. Van Soest PV, Robertson J, Lewis B (1991) Methods for dietary fiber, neutral detergent fiber, and nonstarch polysaccharides in relation to animal nutrition. J Dairy Sci 74(10):3583-3597

21. Angelidaki I, Alves M, Bolzonella D, Borzacconi L, Campos J, Guwy A, Kalyuzhnyi S, Jenicek P, Van Lier J (2009) Defining the biomethane potential (BMP) of solid organic wastes and energy crops: a proposed protocol for batch assays. Water Sci Technol 59(5):927-934

22. Kreuger E, Sipos B, Zacchi G, Svensson S-E, Björnsson L (2011) Bioconversion of industrial hemp to ethanol and methane: the benefits of steam pretreatment and co-production. Bioresour Technol 102(3):3457-3465

23. Raposo F, Fernández-Cegrí V, De la Rubia M, Borja R, Béline F, Cavinato C, Demirer G, Fernández B, Fernández-Polanco M, Frigon J (2011) Biochemical methane potential (BMP) of solid organic substrates: evaluation of anaerobic biodegradability using data from an international interlaboratory study. J Chem Technol Biotechnol 86(8):1088-1098

24. Oliveira L, Cordeiro N, Evtuguin D, Torres I, Silvestre A (2007) Chemical composition of different morphological parts from 'Dwarf Cavendish' banana plant and their potential as a non-wood renewable source of natural products. Ind Crop Prod 26(2):163-172

25. Angelidaki I, Ellegaard L (2003) Codigestion of manure and organic wastes in centralized biogas plants. Appl Biochem Biotechnol 109(1-3):95-105

26. Shen S, Nges IA, Yun J, Liu J (2014) Pre-treatments for enhanced biochemical methane potential of bamboo waste. Chem Eng J 240:253-259

27. Li M-F, Fan Y-M, Xu F, Sun R-C, Zhang X-L (2010) Cold sodium hydroxide/ urea based pretreatment of bamboo for bioethanol production: characterization of the cellulose rich fraction. Ind Crop Prod 32(3):551-559

28. Cordeiro N, Belgacem M, Torres I, Moura J (2004) Chemical composition and pulping of banana pseudo-stems. Ind Crop Prod 19(2):147-154

29. Izumi K, Okishio Y-k, Nagao N, Niwa C, Yamamoto S, Toda T (2010) Effects of particle size on anaerobic digestion of food waste. Int Biodeter Biodegr 64(7):601-608

30. Tumutegyereize P, Muranga F, Kawongolo J, Nabugoomu F (2013) Optimization of biogas production from banana peels: effect of particle size on methane yield. Afr J Biotechnol 10(79):18243-18251

31. Romano RT, Zhang R, Teter S, McGarvey JA (2009) The effect of enzyme addition on anaerobic digestion of JoseTall Wheat Grass. Bioresour Technol 100(20):4564-4571

32. Yang B, Dai Z, Ding S-Y, Wyman CE (2011) Enzymatic hydrolysis of cellulosic biomass. Biofuels 2(4):421-449

33. El-Mashad HM, Zhang R (2010) Biogas production from co-digestion of dairy manure and food waste. Bioresour Technol 101(11):4021-4028

34. Lehtomäki A, Huttunen S, Rintala J (2007) Laboratory investigations on co-digestion of energy crops and crop residues with cow manure for methane production: effect of crop to manure ratio. Resour Conserv Recycl 51(3):591-609

35. Kalia V, Sonakya V, Raizada N (2000) Anaerobic digestion of banana stem waste. Bioresour Technol 73(2):191-193

36. Cheng S, Li Z, Xu C, Yang L (2009) Experimental study on biochemical methane potential of banana tree waste

37. Khan MT, Maurer C, Argyropoulos D, Brule M, Mueller J (2009) Anaerobic digestion of banana waste, a potential source of energy in Uganda. In: Proceedings Tropentag (2009): International Research and Food Security

38. Zainol N (2012) Kinetics of biogas production from banana stem waste. InTech, Biogas Europe, p 408

39. Hernández-Berriel MC, Márquez-Benavides L, González-Pérez D, BuenrostroDelgado O (2008) The effect of moisture regimes on the anaerobic degradation of municipal solid waste from Metepec (Mexico). Waste Manage 28:S14-S20

40. Pommier S, Chenu D, Quintard M, Lefebvre X (2007) A logistic model for the prediction of the influence of water on the solid waste methanization in landfills. Biotechnol Bioeng 97(3):473-482

41. Bourgeois C, Mescle J, Zucca J (1996) Microbiologie alimentaire. Lavoisier, Tome 1 Paris, p 672

42. Pommier S, Chenu D, Quintard M, Lefebvre X (2007) A logistic model for the prediction of the influence of water on the solid waste methanization in landfills. Biotechnol Bioeng 97:473-482 